\section{Transformation of an Ancient Crop: Preparing California 'Manzanillo' Table Olives for Mechanical Harvesting}

\author{
Louise Ferguson $^{1,3}$ and Sergio Castro Garcia ${ }^{2}$
}

ADDITIONAL INDEX WORDs. alternate bearing index, mechanical pruning, Olea europaea

SUMMARY. As one of the oldest continuously produced tree crops in the world, it is ironic that table olive (Olea europaea) production has benefitted from few technological innovations, including harvesting. Two harvesting technologies, trunk shaking and canopy contact, have been identified. In a 2013 trial, a prototype canopy contact harvester successfully harvested $92 \%$ of a 5.3-ton/acre mechanically pruned crop, vs. $81 \%$ for a 12.8 -ton/acre hand-pruned control crop in a 19-yearold, $13 \times 26$-ft grove, spaced at 139 trees/acre and adapted for mechanical harvesting with 6 years of mechanical topping and hedging. About $85 \%$ of the handpruned olives were cannable vs. 86\% of the mechanically pruned olives. Over the 6 years of mechanical pruning, the mechanically pruned trees averaged an annual 4.2 tons/acre vs. 5.3 tons/acre with hand-pruned trees. Again in 2013, this same canopy contact harvester achieved $81 \%$ final harvester efficiency with a 5.8-ton/acre crop in a 12-year-old, $12 \times 18$-ft, 202-tree/acre, mechanically pruned hedgerow grove vs. $80 \%$ efficiency for a 5.17-ton/acre crop with hand-pruned hedgerow trees. Similarly, no significant differences in the percentage of cannable olives, fruit size distribution, or value per ton was produced by the pruning treatments. In this trial in which both hand and mechanical pruning were used to produce a hedgerow, the hand-pruned trees averaged 3.7 tons/acre vs. 4.3 tons/acre for mechanically pruned trees. In a commercial trial in 2012 , the trunk-shaking harvester achieved $77 \%$ average harvester efficiency in a 40 -acre, 180 -tree/acre grove, with a 4 -ton/ acre crop prepared with both hand and mechanical pruning. These ongoing trials indicate that adapting groves with mechanical pruning does not decrease average annual yields and can produce table olive groves that can be mechanically harvested at a cost and speed that is competitive with hand harvesting.

C alifornia's table olive industry is built upon the cultivar Manzanillo that is harvested green, before full maturity. It becomes the California black ripe table olive through oxidation from green to black in processing. Increasingly, California table olive production, with its current combination of rising hand harvest costs and stagnant per ton

This paper was part of the colloquium "Strategy for Developing Mechanical Harvesting of Horticultural Crops: Simultaneous Short-, Medium-, and Longterm Strategies" held 24 July 2013 at the ASHS Annual Conference, Palm Desert, California, and sponsored by the Production and Harvest Mechanization $(\mathrm{MECH})$ Working Group

We gratefully acknowledge the support of the California Olive Committee, the cooperation of Bell Carter Foods Inc., Musco Family Olive Co., Rocky Hill Ranch, Burreson Groves, Nickles Soils Laboratory, Erick Nielsen Enterprises Inc., Gold Country Hydraulics \& Hose Inc., and our international cooperators in Spain, Argentina, and Portugal.

${ }^{1}$ Department of Plant Sciences, University of California Davis, One Shields Ave., Davis, CA 95616

${ }^{2}$ Department of Rural Engineering, Agrónomos y Montes, University of Cordoba, Campus de Rabanales, Centrales Nacional IV Km 396, Cordoba, Spain ${ }^{3}$ Corresponding author. E-mail: LFerguson@UCDavis. edu. prices, is not economically sustainable (Ferguson et al., 2010). The industry is currently slightly under 22,000 acres and declining (Warnert, 2011). Hand harvest costs are volatile, often exceeding $50 \%$ to $75 \%$ of gross return, crop value has not increased in tandem with harvest labor costs, and competition for the aging and lessskilled hand labor pool has increased (California Farm Bureau Federation, 2012). As with most of California's horticultural crops, if the table olive industry continues to rely on hand harvesting, it is only a matter of time before table olives are no longer produced in California (Sarig, 2012; Sarig et al., 2000). The only realistic solution is to develop economically feasible mechanical harvesting. Mechanical harvesting has three components. The first is a harvesting technology able to remove and catch the fruit without economic damage to the crop or tree. The second is a grove trained and pruned to facilitate harvesting. The third is a "fruit loosener," a chemical that can facilitate harvesting by accelerating the normal ripening process of fruit abscission.

'Manzanillo', the major California black ripe processed table olive cultivar, poses specific impediments to mechanical harvesting. Most traditional California table olive trees are large, generally over $18 \mathrm{ft}$ tall with 12 to 18 - $\mathrm{ft}$-wide canopies (Fig. 1). The fruit is borne on the flexible pendulous shoots of the previous season's growth of in a 2- to $3-\mathrm{ft}$ shell over the entire canopy. 'Manzanillo' olives destined for black ripe processing are harvested physiologically immature, before the abscission zone has initiated the decrease in removal force that accompanies fruit maturity. The immature olives seldom have a detachment force less than $2 \mathrm{~N}$ and usually as high as $10 \mathrm{~N}$ (Ferguson et al., 2010). Additionally, the olives are small, weigh less than $0.5 \mathrm{oz}$, and bruise easily. However, 'Manzanillo' olives used for processing as California black ripe table olives have one advantage for mechanical harvesting. In postharvest processing, they are oxidized from green to black, which masks superficial bruises. As Zipori et al. (2014) recently demonstrated, mechanically harvested 'Manzanillo' olives could not be successfully processed as marketable green olives.

Developing mechanical harvesting for any tree crop follows the same experimental sequence. First a successful

\begin{tabular}{lllc}
\hline $\begin{array}{l}\text { Units } \\
\text { To convert U.S. to SI, } \\
\text { multiply by }\end{array}$ & U.S. unit & SI unit & $\begin{array}{l}\text { To convert SI to U.S., } \\
\text { multiply by }\end{array}$ \\
\hline 0.4047 & $\mathrm{acre}(\mathrm{s})$ & $\mathrm{ha}$ & 2.4711 \\
0.3048 & $\mathrm{ft}$ & $\mathrm{m}$ & 3.2808 \\
0.0283 & $\mathrm{ft}^{3}$ & $\mathrm{~m}^{3}$ & 35.3147 \\
0.4536 & $\mathrm{lb}$ & $\mathrm{kg}$ & 2.2046 \\
4.4482 & $\mathrm{lbf}$ & $\mathrm{N}$ & 0.2248 \\
1.6093 & $\mathrm{mph}$ & $\mathrm{km} \cdot \mathrm{h}^{-1}$ & 0.6214 \\
28.3495 & $\mathrm{oz}$ & $\mathrm{g}$ & 0.0353 \\
6.8948 & $\mathrm{psi}$ & $\mathrm{kPa}$ & 0.1450 \\
2.2417 & $\mathrm{ton}(\mathrm{s}) / \mathrm{acre}$ & $\mathrm{Mg} \cdot \mathrm{ha}^{-1}$ & 0.4461
\end{tabular}




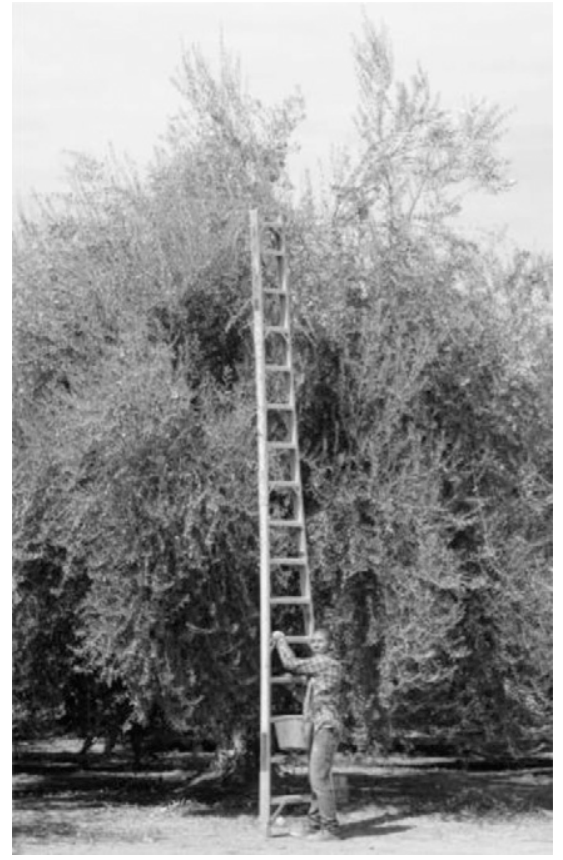

Fig. 1. A traditional 'Manzanillo' table olive tree and olive picker with an $18-\mathrm{ft}$ $(5.5 \mathrm{~m})$ kick-leg ladder, $20-\mathrm{lb}(9.1 \mathrm{~kg})$ bucket, and woven cotton picking gloves.

fruit removal method is identified and developed, or more usually adapted from other crops. Second, the harvesting technology is tested to ensure it produces fruit that can be successfully marketed and does not inflict lasting damage to the tree. These first two steps can be done within university research programs. The third step consists of simultaneously modifying the prototype harvester and the existing groves, then evaluating the combination for efficiency and operating parameters of ground speed, tons, and acres per hour. University research programs seldom produce more than a prototype, often without a mobile platform and catch frame. Incorporation of these harvester components, and subsequent testing, is generally done in cooperation with commercial fabricators. In this review, the summarized data presented for the trunk-shaking harvester was generated in a commercial trial, with a commercially available harvester and the research is now completed. The data summarized for the canopy contact harvester was generated with a prototype in randomized, replicated trials and is continuing.

Initially, we simultaneously investigated all three components of mechanical harvesting, harvest method, grove adaptation, and identifying a loosening agent. Good progress has been made with the first two components, the harvester and the groves, but investigations of abscission compounds have ceased. Two harvesting technologies and their weak and strong points have been identified and modified. A traditional grove adapted for mechanical harvesting with mechanical pruning and a newly established mechanically harvestable hedgerow grove have been evaluated. The initial experiments on abscission compounds, consistent with the later more focused work of Zipori et al. (2014), demonstrated the best potential candidates, ethylene-generating compounds, produced inconsistent results (Burns et al., 2008). Therefore, all subsequent research has focused on improving the mechanical harvester through engineering and on adapting current groves with mechanical pruning and developing new groves.

\section{Developing mechanical olive harvesting}

After the first stage of determining and eliminating the most limiting factors of fruit or tree damage, (Castro-Garcia et al., 2009) evaluating mechanical harvester efficiency is straightforward. Matched sets of tree rows are selected for mechanical harvesting and hand harvest controls. Tree rows are a better experimental unit than individual trees as it is difficult to separate yields in individual trees and rows allow groundspeed evaluation. Before harvest, fruit removal force is measured. During mechanical harvesting, fruit caught in the catch frame is weighed. Fruit on the ground that was mechanically harvested but not caught in the catch frame is collected and weighed. Fruit remaining in the tree is then handharvested. The weight of the fruit in the catch frame, divided by the weight of all three fractions, or total tree crop load, determines final harvester efficiency expressed as a percentage as follows: weight caught in the harvester catch frame $\div$ (weight caught in catch frame + weight on ground + weight gleaned from the tree).

The weight of fruit on the ground divided by the sum of it and that caught in the catch frame can give a good indication of the catchframe competence, often an issue in mechanical harvester development. Hand harvesting of a matched control row is the control for harvester efficiency. A $100 \%$ efficiency is assumed for hand-harvest crews. However, measurements suggested hand harvest crew efficiency ranges from 93\% to $97 \%$ (Ferguson et al., 2010).

Olive value is a function of yield, individual fruit size, stage of ripeness, and fruit condition. For mechanically harvested olives, the quality control is hand-harvested olives. In these experiments, the fresh hand-harvested control and machine-harvested row samples were graded at a commercial receiving station. The mechanically and handharvested control row replications were maintained separately through grading and processing to facilitate organoleptic evaluation by two panels. The combined analyzed evaluations by a trained sensory panel for quality and defects, and a consumer panel for preferences, produce what a food scientist calls "drivers of liking" (Ferguson et al., 2010). These are the qualities that make consumers like the olives, and presumably what an industry should strive for. Currently, these two experimental postprocessing tests are not done commercially as individual grower lots are combined for processing. However, for accurate grower payment, it will eventually be important to correlate the grade given at a receiving station with the evaluation of the final processed product. If mechanically harvested olives receive a lower grade, and payment, due to superficial bruises that do not decrease the quality of a processed olive, then grower payment will not accurately reflect the market value of the processed olives.

\section{Table olive harvesters evaluated in California}

Two mechanical harvesting technologies have been identified for California black ripe processed table olives. Commercially available trunkshaking harvesters (Fig. 2) were adapted from pistachios (Pistacia vera) and prunes (Prunus domestica). The prototype canopy contact harvester (Fig. 3) was adapted from a wine grape (Vitis vinefera) and experimental jatropha (Jatropha curcas) harvesters. Both harvesting technologies have strengths and weaknesses. Trunk shakers remove fruit by transmitting shake from the head clamped on the trunk vertically, 


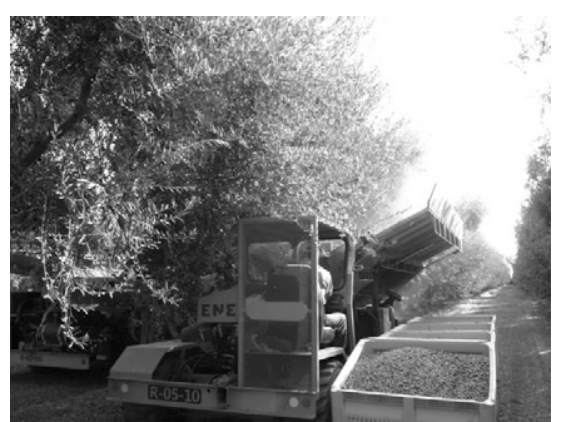

Fig. 2. An olive trunk shaker with a two-sided catch frame and a bin dumping system adapted from pistachio harvesters. Trunk shakers are most efficient with young olive trees that have smooth trunks, upright growth habit, short stiff scaffolds, and lighter crops.

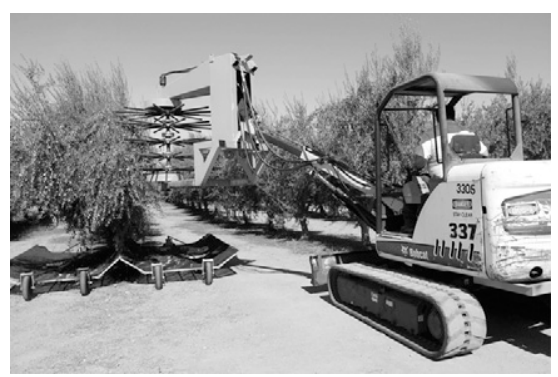

Fig. 3. A prototype olive canopy contact harvester adapted from grape and jatropha harvesters. Canopy contact harvesters are more efficient with hedgerow groves that can present a flat wall of fruit to the harvester head.

horizontally out the main scaffolds, and vertically down the hanging shoots. The shaking force decreases with distance from the shaker head and as branch angle from the vertical increases. Trunk shakers are more efficient for shorter trees with stiff, upright scaffolds, lighter canopies, and lighter crops with larger fruit (Hartmann et al., 1975). Canopy contact harvesters remove fruit when the horizontal motion of the tines strikes the vertical shoots. They are most efficient when a grove is trained to a hedgerow and maintained with hedging and topping to form a fruiting wall no taller than the canopy contact head. With both harvest technologies, the fruit borne on the canopy top is the most difficult to remove. For trunk shakers, the force of the shake has dissipated before reaching the top of the canopy. For canopy contact heads, the tines cannot reach the top fruit unless the head is manipulated, which slows the harvester. Eventually, as with mechanically pruned and harvested oil olives, the upper canopy crop may need to be pruned off annually to facilitate mechanical harvesting efficiency.

Both harvesting technologies initially had limiting factors. The major problem with the trunk shaker in Fig. 2 was trunk damage that broke bark and exposed the cambial layer. Early experiments determined decreasing clamping strength below 800 psi, adding additional padding and ensuring operators fully clamped the trunk before shaking decreased this damage (Ferguson et al., 2012). However, the interaction of trunk damage and tree water status needs to be better characterized as fully irrigated trees appear to sustain more trunk damage than deficit-irrigated trees (Ferguson et al., 2010). This is a limitation as table olives are irrigated as late as possible before harvest to ensure better size. The major problem with the canopy contact harvester shown in Fig. 3 was that early versions of the machine badly bruised the olives. Early experiments identified two sources of fruit bruising. First, any surface the olive contacted during harvest, the harvester head rods or machine surfaces, caused bruising. Padding the harvester head rods and all machine surfaces with loose Shore $60 \mathrm{~A}$ padding sharply decreased the bruising (Castro-Garcia et al., 2009). Shore hardness specifies the methods for determining the hardness of materials by means of durometers of two types: type A for softer materials and type D for harder materials (Wikipedia, 2014). Shore 60A padding has roughly the same rubber parameters as car tire tread. Second, there is a strongly positive relationship between the force applied by the harvester rods, the acceleration produced in the detaching fruit, and fruit bruising. Once the displacement and force required to remove the olives was determined, the harvester head frequency could be set to decrease bruising (Castro-Garcia et al., 2009).

Experimental trials from 2006 through 2012 achieved the first two experimental steps of identifying and developing harvesting technologies and decreasing fruit and tree damage. Both trunk shaker and canopy contact harvester technologies were demonstrated to effectively remove fruit without decreasing processed fruit marketability, or the tree health and longevity. Harvesting the olives before they were overripe and delivering them for processing within $24 \mathrm{~h}$ maintained fresh and processed fruit quality. If these conditions were met, the olives from both harvesting technologies received processor grades and values equal to those of handharvested olives. Further, neither sensory nor consumer experimental panels could distinguish the mechanically harvested from hand-harvested fruit after processing. With these results, the two most limiting factors to developing mechanical olive harvesting had been achieved, producing marketable processed fruit without long-term tree damage (CastroGarcia et al., 2012; Ferguson et al., 2010).

The third experimental step for both harvesting technologies was achieving the $80 \%$ final harvester efficiency required for economically feasible mechanical harvesting (Klonsky et al., 2011). To achieve $80 \%$ harvest efficiency required adaptation of the second component of mechanical harvesting, the groves. The following discussions summarize the results of a now completed commercial trunkshaking harvester trial and two ongoing canopy contact harvester trials. In all three trials, the groves were extensively adapted with both hand and mechanical pruning.

\section{Commercial evaluation of trunk-shaking harvester for 'Manzanillo' black ripe table olives}

By 2012, research with the trunk-shaking harvesting technology had advanced enough to do a commercial trial with a modified commercially available harvester. This was not a controlled experimental trial with hand-harvested fruit quality and value controls. The objective of this trial was to determine time and cost to harvest an acre and a ton of olives. The goal was to determine if trunk shaking was economically and logistically competitive with hand harvesting. The 40-acre, 15-year-old, $14 \times$ 17-ft, 180-tree/acre, 'Manzanillo' grove was planted in an east-west orientation. Before 2011, the grove had been trained to the singletrunked vase-shape standard for table 
olive trees in California. In 2011 and 2012, the grove was prepared for trunk-shaker mechanical harvesting by interior canopy hand pruning to remove limbs that would interfere with the harvester clamp and catchframe wings. Large limbs below $45^{\circ}$ from the vertical axis of the tree, those projecting directly into the row middle and those previously demonstrated to shake harvest poorly, were also removed. Tree size was reduced in 2011 by $\approx 25 \%$ with mechanical topping and hedging. The final tree canopy was $12 \times 8 \times 8 \mathrm{ft}$, and $3 \mathrm{ft}$ up from the ground with a volume of $576 \mathrm{ft}^{3}$. Mechanical pruning in 2011 , but not 2012, allowed the mechanically pruned shoots to produce buds for crop in 2012. Preharvest fruit removal force measurements taken the same day ranged from 1 to $3 \mathrm{lbf}$. The grove was mechanically harvested with the double-sided trunk shaker with a bin carrying and dumping system shown in Fig. 2. Harvest time per row, including turn around and bin dumping, was recorded. Yield per row was weighed. The time per tree, acre, and ton was calculated using these values. Final harvester efficiency was obtained by hand harvesting 10 trees/row in 10 rows after mechanical harvesting. This weight was then combined with the calculated mechanically harvested weight for 10 trees from the same row and the calculated average efficiency was the percentage produced by dividing the handharvested gleaning weight by the sum of it and the average weight of 10 mechanically harvested trees per row.
The trunk-shaking harvester averaged $53 \mathrm{~s} /$ tree, 0.35 acres $/ \mathrm{h}$, and 2.3 tons $/ \mathrm{h}$. As the trial progressed, harvesting times per tree steadily decreased to $\approx 40 \mathrm{~s} /$ tree, 90 trees $/ \mathrm{h}$, or 0.5 acre $/ \mathrm{h}$, and $\approx 3$ tons $/ \mathrm{h}$. The calculated harvester efficiency ranged from $65 \%$ to $85 \%$ and averaged $77.5 \%$ final harvester efficiency, and increased as the trial progressed. An economic analysis converting the recorded data from this 40 -acre field trial to a standard 7.5-acre grove with a 4-ton/acre crop is given in Table 1 . At the average 2.3 tons $/ \mathrm{h}$ achieved in this trial, the final cost was $\$ 173 /$ harvested ton. However, this cost does not include hauling and associated contract harvester costs for labor to follow the harvester repairing trunks with broken bark, cutting out unharvested or broken branches to improve harvester efficiency and crew field support such as sanitary facilities, and hauling costs. Therefore, an estimate of $\$ 200$ per harvested and delivered ton is conservative. For analysis, we used the average accepted historical hand-harvest efficiency (Klonsky et al., 2011). The best hand picker can harvest 1 ton, (fifty 40 -lb buckets), in a 10-h day. A 30-man crew can harvest 30 tons ( 7.5 acres at 4 tons/ acre) in 10-h day (Klonsky et al., 2011). Using a midrange historical $\$ 400 /$ ton harvesting cost, harvesting 30 tons would cost $\$ 12,000$. In the 2012 commercial field trial, the conservative estimate of $\$ 200 /$ ton the trunk shaker harvested the same 30 tons at $77.5 \%$ efficiency in $10 \mathrm{~h}$. The harvested 23.25 tons cost $\$ 4650$ to mechanically harvest. In this trial, the grower received an average of $\$ 1005 /$ ton, or $\$ 23,366$ gross for 23.25 tons of mechanically harvested olives minus $\$ 4650$ for mechanical harvesting and received $\$ 18,716$ net. Hand harvesting 30 tons at $100 \%$ efficiency would result in a gross return of $\$ 30,150$ gross minus $\$ 12,000$ for picking to net $\$ 18,150$. For 30 tons in the field mechanically harvesting at $77.5 \%$ efficiency results in a positive difference of $\$ 566$ total: $\$ 18,716$ gross net for machine harvested olives minus $\$ 18,150$ gross net for hand-harvested olives. If calculated on a per acre basis, the mechanical harvesting produced $\$ 76 /$ acre more; \$2496 net for mechanically harvested olives vs. $\$ 2420$ for handharvested olives at this spacing and yield per acre. Calculated on a per ton basis, the mechanically harvested olive net return was $\$ 200 /$ ton more; $\$ 805 /$ ton net return for mechanically harvested olives vs. $\$ 605 /$ ton net return for hand-harvested olives.

This is a conservative analysis. If the fact that pickers in reality harvest only $93 \%$ to $95 \%$ of the crop in the tree, not the $100 \%$ assumed in this calculation, this comparison is conservative and cost of mechanically harvesting olives at $77.5 \%$ efficiency is economically competitive. Additionally, during harvest, branches with poor removal, or branches that break, are pruned, as the former will continue to harvest poorly and the latter are incompatible with successful trunk shaking. This will improve mechanical harvesting efficiency in successive seasons. Finally, the trunk-shaking harvesters are available when hand labor is

Table 1. Comparison for 2012 costs and net return for hand harvest ( 30 pickers) versus trunk shaker mechanical harvest of 'Manzanillo' table olives. The right hand column details the projected hand harvesting costs and net returns from the University of California Cost Studies (Klonsky et al., 2011) for typical 7.5-acre (3.04 ha) grove with a 4-ton/acre (9.0 $\mathrm{Mg} \cdot \mathrm{ha}^{-1}$ ) yield using the values per ton obtained in our commercial trial. The left hand column of the table uses the same grove dimensions and values per ton but with the calculated trunk shaker efficiency obtained in our 40-acre commercial trial 9 Oct. 2012. This table demonstrates that mechanically harvesting the same 30 tons $(27.2 \mathrm{Mg})$ total at an average $77.5 \%$ efficiency would result in $\$ 200 /$ ton greater net return per ton versus hand harvesting.

\begin{tabular}{llc}
\hline & \multicolumn{1}{c}{ Trunk shaker harvest costs ${ }^{\mathrm{z}}$} & Hand harvest cost \\
\hline Grove parameters & 30 tons at 4 tons/acre on 7.5 acres & 30 tons at 4 tons $/$ acre on 7.5 acres \\
Final harvested efficiency (calculated by wt) & $77.5 \%$ & $100 \%$ \\
Time to harvest & $10 \mathrm{~h}$ & $10 \mathrm{~h}$ \\
Price for harvesting & $\$ 200 /$ ton & $\$ 400 /$ ton \\
Price paid/harvested & $\$ 1,005 /$ ton & $\$ 1,005 /$ ton \\
Net gross payment - harvest costs & $\$ 23,366$ gross $-\$ 4,650$ & $\$ 30,150$ gross $-\$ 12,000$ \\
net return per 7.5 acres harvested & harvest $=\$ 18,716$ net & harvest $=\$ 18,150$ net \\
Net return per acre & $\$ 2,496 /$ acre & $\$ 2,420 /$ acre \\
Net return per ton & $\$ 805 /$ ton & $\$ 605 /$ ton \\
\hline
\end{tabular}

${ }^{\mathrm{z}} \$ 1 / \mathrm{ton}=\$ 1.1023 / \mathrm{Mg}, \$ 1 / \mathrm{acre}=\$ 2.4711$ 
not. Table olives, grapes, and mandarins (Citrus reticulata) are harvested at the same time as olives and have the competitive advantage of not requiring ladders. Trunk shakers are available because pistachio harvest has finished by early October when table olive harvest begins.

\section{Evaluation of canopy contact harvester for 'Manzanillo' table olives}

Experimental trials incorporating both engineering improvements of the

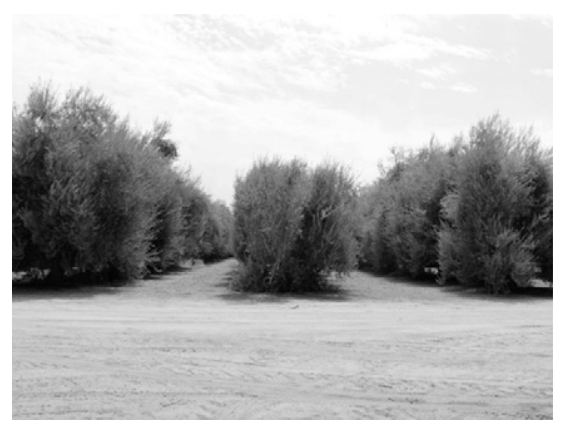

Fig. 4. The center tree row has been mechanically pruned to produce a 'Manzanillo' table olive tree that will harvest more efficiently with a canopy contact harvester. Mechanical pruning reduced these tree canopies $58 \%$ in volume from 2912 to $1248 \mathrm{ft}^{3}(82.5$ to $35.3 \mathrm{~m}^{3}$ ), but only decreased yield $21 \%$. The canopy contact harvester removed $\mathbf{9 2 \%}$ of the fruit from the mechanically pruned center row vs. $80 \%$ from the hand-pruned row to the left. prototype canopy contact harvester and adaptation of existing or development of new groves to improve final harvester efficiency are ongoing. As with the trunk-shaking harvester, the goal is $80 \%$ final harvester efficiency. Earlier trials have demonstrated the canopy contact harvesters could produce black ripe processed fruit, which neither trained sensory, nor consumer panels, could distinguish from handharvested fruit (Ferguson et al., 2010). Therefore, the ongoing trials are focusing exclusively on improving harvesting efficiency through harvester engineering and canopy management. These two trials, the first in an adapted adaptation existing 139-tree/acre grove, and the second in a new moderatedensity 202-tree/acre hedgerow grove, are summarized below. Our hypothesis was that training the canopy into flat a fruiting wall no taller than the canopy contact head will facilitate access to the fruit and continuous harvesting at 0.25 to $0.50 \mathrm{mph}$ or 0.5 to $1 \mathrm{acre} / \mathrm{h}$.

\section{Adapting existing groves for canopy contact harvesters}

To adapt existing groves for mechanical harvesting with canopy contact harvesters, the tree size had to be significantly reduced. The traditional 139-tree/acre 'Manzanillo' grove in Fig. I was transformed into the modified grove shown in Fig. 4. The 6year sequence of mechanical topping and hedging pruning treatments that modified these groves is given in Table 2. In 2008, the tree canopies measured $18 \times 16 \times 13 \mathrm{ft}$, and when pruned $3 \mathrm{ft}$ from the ground had an average canopy volume of $2912 \mathrm{ft}^{3}$. When mechanically pruned in a 3 year cycle in which the east side of the row was first hedged $6 \mathrm{ft}$ from the trunk, the following year the row was topped at $12 \mathrm{ft}$, and the third year the west side was hedged $6 \mathrm{ft}$ from the trunk, the canopy volume was decreased by $58 \%$, to the $1248 \mathrm{ft}^{3}$ shown in Fig. 4. Annual limited hand pruning, no more than $6 \mathrm{~min} /$ tree, was done inside the canopy. While the objective was to reduce tree size for more efficient mechanical pruning, annual economic yields were also needed. Pruning one-third of the canopy in 3 successive years allowed vegetative shoots to grow the year of pruning, have growth with fruit buds the subsequent year, and fruit production the third year. This cycle allowed at least one-third of the canopy to be producing every year. The cycle was then repeated on the fourth year. Thus far, this has been effective strategy for side hedging. However, due to strong regrowth, topping was done in successive years.

The effects of 6 years of pruning on annual and average bearing can be seen in Table 2 . Even though industrywide weather-related crop failures in 2008,2009 , and 2012 have compromised the data, the effects of the

Table 2. Effect of mechanical topping and hedging on yield and canopy contact harvester efficiency of 'Manzanillo' table olives in 2008-13. This table demonstrates the effect of mechanical topping and hedging over a 6-year period on annual and average annual yields. While the total crop failures in 2008,2009 , and 2012 disrupted yielding, this data demonstrates mechanical pruning decreased the wide variation in yield and increased mechanical harvesting efficiency.

\begin{tabular}{|c|c|c|c|c|c|c|c|}
\hline Harvest & $2008^{z}$ & $2009^{z}$ & 2010 & 2011 & $2012^{\mathrm{z}}$ & 2013 & $\begin{array}{c}\text { Avg annual } \\
\text { yield (tons/acre) }\end{array}$ \\
\hline $\begin{array}{l}\text { Pruning treatment } \\
\text { (distance from trunk } \\
\text { or soil surface) })^{\mathrm{y}}\end{array}$ & $\begin{array}{l}\text { Hedged } \\
\text { West: } 6 \mathrm{ft} \\
\text { Topped: } \\
12 \mathrm{ft}\end{array}$ & $\begin{array}{l}\text { Hedged } \\
\text { East: } 6 \mathrm{ft} \\
\text { Topped: } \\
12 \mathrm{ft}\end{array}$ & & $\begin{array}{l}\text { Hedged } \\
\text { West: } 6 \mathrm{ft}\end{array}$ & $\begin{array}{l}\text { Hedged } \\
\text { East: } 6 \mathrm{ft} \\
\text { Topped: } \\
12 \mathrm{ft}\end{array}$ & $\begin{array}{l}\text { Topped: } \\
12 \mathrm{ft}\end{array}$ & \\
\hline $\begin{array}{l}\text { Mechanically pruned } \\
\text { yield (tons } / \text { acre })^{\mathrm{y}}\end{array}$ & 1.3 & 0.1 & $9.5^{*} b^{x}$ & $7.9^{* *} \mathrm{a}$ & 1.0 & $5.3^{* * *} b$ & 4.2 \\
\hline $\begin{array}{l}\text { Hand-pruned control } \\
\text { (tons/acre) }\end{array}$ & 1.5 & 0.2 & $12.4^{*} \mathrm{a}$ & $2.8 * * b$ & 2.3 & $12.8^{* * *} \mathrm{a}$ & 5.3 \\
\hline $\begin{array}{l}\text { Harvester efficiency } \\
\text { (removal by wt) }\end{array}$ & & & & & & $81 \%$ & \\
\hline
\end{tabular}

${ }^{\mathrm{z}}$ Industry-wide weather-related crop failures in these years

y l ton $/$ acre $=2.2417 \mathrm{Mg} \cdot \mathrm{ha}^{-1}, \mathrm{l} \mathrm{ft}=0.3048 \mathrm{~m}$.

'Yields followed by different letters within columns are significantly different by analysis of variance at the $5 \%$ level. Significance within columns by least-squares means: $* * *, * *, *$, NS $(0.001,0.01,0.05$, not significant, respectively) 
pruning treatments on subsequent years' yields were significant. In 2010 and 2011, the mechanically pruned trees produced 9.5 and 7.9 tons/acre vs. the 12.4 and 2.8 tons/ acre the produced by the handpruned control trees. The 2014 harvest will demonstrate if mechanical pruning can repeat this pattern. Thus far, from 2008 through 2013, the mechanically pruned trees have produced an average of 1.1 tons/acre less than the hand-pruned trees, an annual average of 4.2 vs. 5.3 tons/acre for the mechanically and hand-pruned trees, respectively. The pruning treatments also produced differences in the percentages of individual size ranges of fruit. Generally, the heavier the crop load, the lower the percentage of medium, large, and extralarge fruit (data not shown). There was a statistically

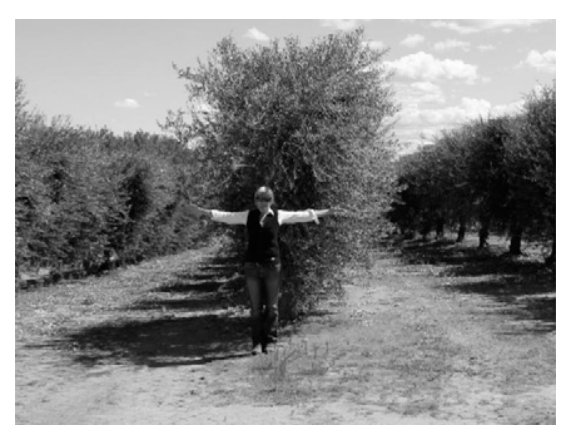

Fig. 5. This 12 -year-old, $12 \times 18$-ft $(3.7 \times 5.5 \mathrm{~m}), 202$-tree/acre $(499.2$ trees/ha), moderate-density hedgerow 'Manzanillo' table olive grove has been maintained with both hand and mechanical annual pruning. Both pruning methods have produced canopies with volumes of $\approx 324 \mathrm{ft}^{3}$ $\left(9.2 \mathrm{~m}^{3}\right)$ with no significant differences in yield or harvest efficiency with a canopy contact harvester. insignificant 0.11 difference in the calculated alternate bearing index between the mechanically and hand trees, averaging 0.62 and 0.51 , respectively (Monselise and Goldschmidt 1982). This is probably a function of the weather related crop failures in 2008, 2009, and 2012 confounding the effects of the mechanical pruning on bearing.

On 26 Sept. 2013, the most recent improved version of the prototype canopycontact harvester was evaluated in both mechanically and hand-pruned rows using the harvesting procedures described earlier. The canopy contact prototype harvester successfully removed $92 \%$ of a 5.3 -ton/acre crop on mechanically pruned trees vs. $81 \%$ of the 12.8-ton/acre crop on handpruned trees. There were no significant differences in quality or value of the hand-harvested vs. the mechanically harvested fruit. This trial will be continued through 2014. The results thus far indicate mechanical pruning can be used to adapt traditional olive canopies to a size and shape that can be successfully harvested mechanically without decreasing average annual yields.

Similar results were obtained in a 12 -year-old hedgerow grove (Fig. 5), developed specifically for mechanical harvesting with a canopy contact head harvester. The 10 -year-old, $12 \times 18$-ft, 202 -tree/acre grove was mechanically or hand-pruned to a $12 \times 6 \times 6-\mathrm{ft}$ canopy and $3 \mathrm{ft}$ from the ground. The reduced tree canopy volume was 324 $\mathrm{ft}^{3}$ for both pruning methods. The objectives were to demonstrate a moderate-density hedgerow grove could be maintained with either hand or mechanical pruning, and produce economic yields. A second objective was to determine if either pruning method made mechanical harvesting more efficient.

Over the three seasons, 2011 through 2013 , including the weatherrelated crop failure in 2011 , the hand and mechanical pruning treatments statistically insignificant yields and crop values. In 2012 and 2013, the hand-pruned trees produced 6.7 and 5.1 tons/acre, averaging 3.7 tons/ acre, vs. 5.1 and 5.2 tons/acre, averaging 3.7 tons/acre for the mechanically pruned trees. In both years, there were no statistically significant differences in percentages of cannable fruit, fruit size distributions, or value. Both treatments produced crops of sufficient economic levels for commercial production. This trial will be continued for through 2017. However, results thus far indicate moderatedensity hedgerow groves can be developed and maintained with either hand or mechanical pruning and produce economically competitive yields.

The canopy contact harvester was evaluated for efficiency 5 Oct. 2012 and 10 Oct. 2013 using the procedures described earlier. As can be seen in Table 3 , the harvester efficiency improved from $70 \%$ in 2012 to $77 \%$ in 2013 for hand-pruned trees. Similarly, for mechanically pruned trees, final harvester efficiency improved from $77 \%$ to $81 \%$. In both seasons, there were no differences in quality or value of the mechanically vs. manually harvested fruit.

\section{Effect of canopy volume on yield}

The collective results in this review also suggest a strong parallel with the mechanically pruned and harvested hedgerow olive oil groves

Table 3. Effect of mechanical topping and hedging on the yield of 'Manzanillo' table olives in 2008-13. This data in this table demonstrates both hand and mechanical pruning produced hedgerow groves with no differences in yields or harvesting efficiency with a canopy contact harvester.

\begin{tabular}{|c|c|c|c|c|}
\hline Harvest & $2011^{\mathrm{z}}$ & 2012 & 2013 & $\begin{array}{c}\text { Avg annual } \\
\text { yield (tons/acre) }\end{array}$ \\
\hline $\begin{array}{l}\text { Pruning treatment } \\
\quad(\mathrm{ft} \text { from trunk or soil surface })^{\mathrm{y}}\end{array}$ & $\begin{array}{l}\text { Hedged } \\
\text { West } 6 \mathrm{ft}\end{array}$ & $\begin{array}{l}\text { Hedged East: } 6 \mathrm{ft} \\
\text { Topped: } 12 \mathrm{ft}\end{array}$ & Topped: $12 \mathrm{ft}$ & \\
\hline Mechanically pruned yield (tons/acre) & 0.8 & 5.1 & 5.2 & 3.7 \\
\hline Harvester efficiency (removal by wt) & & $77 \%$ & $81 \%$ & \\
\hline Hand-pruned yield (tons/acre) & 0.4 & 6.7 & 5.1 & 4.3 \\
\hline
\end{tabular}

${ }^{z}$ Industry-wide weather-related crop failures in 2011.

${ }^{y} 1$ ton/acre $=2.2417 \mathrm{Mg} \cdot \mathrm{ha}^{-1}, \mathrm{l} \mathrm{ft}=0.3048 \mathrm{~m}$.

${ }^{x}$ Not significantly different between means by analysis of variance within a column at the $5 \%$ level. 
developed in the past decade. The results given here indicate tree canopy volumes can be considerably reduced and still produce marketable yields. The traditional groves adapted for mechanical harvesting with mechanical pruning discussed above sustained a decrease in canopy volume from 2912 to $1248 \mathrm{ft}^{3}$. However, while the canopy volume was reduced by $58 \%$, the yield of the mechanically pruned trees was only reduced by $21 \%$. The smaller mechanically pruned trees produced an annual average of 1.1 tons/acre per year less, 4.2 vs. 5.3 tons/acre produced by the hand-pruned control trees. Similarly, in the trial discussed in which the individual tree canopy volumes of both mechanically and hand-pruned trees were of $324 \mathrm{ft}^{3}$ yet produced average annual yields of 3.7 and 4.3 tons/acre, respectively. This demonstrates that 'Manzanillo' olive trees do not need to have large canopies to generate economically viable crops.

\section{Current status of mechanical harvesting of California black ripe table olives}

Cumulatively, the results summarized in this review demonstrate that that California black ripe 'Manzanillo' table olive groves can be adapted for mechanical harvesting with both hand and mechanical pruning without losing yield. These results also demonstrate both trunk-shaking and canopy contact harvesters can achieve harvesting efficiencies that are financially competitive with hand harvest. The final step, widespread adaptation of mechanical harvesting, will be driven by the availability of mechanical harvesters and the negative factors of labor cost, availability, and ability. California's black ripe table olive industry will not survive without mechanical harvesting.

\section{Literature cited}

Burns, J.K., L. Ferguson, K. Glozer, W.H. Krueger, and R.C. Rosecrance. 2008. Screening fruit loosening agents for black ripe processed table olives. HortScience 43:1449-1453.

California Farm Bureau Federation. 2012. Walking the tightrope: California farmers struggle with labor shortages. California Farm Bureau Federation agricultural employment survey results-2012. 5 May 2014. <http://www.cfbf.com/ cfbf/_documents/issues/CFBF_Farm_ Employment_Survey2012.pdf $>$.

Castro-Garcia, S., G.L. Blanco Roldán, F. Jiménez-Jiménez, J.A. Gil-Ribes, L. Ferguson, K. Glozer, W.H. Krueger, E.J. Fichtner, J.K. Burns, J.A. Miles, and U.A. Rosa. 2012. Preparing the Spain and California table olive industries for mechanical harvesting. Acta Hort. 965:29-40.

Castro-Garcia, S., U.A. Rosa, C.J. Gliever, D. Smith, J.K. Burns, W.H. Krueger, L. Ferguson, and K. Glozer. 2009. Video evaluation of table olive damage during harvest with a canopy shaker. HortTechnology 19:260-266.

Ferguson, L., K. Glozer, C. Crisosto, U.A. Rosa, S. Castro-Garcia, E.J. Fichtner, J.X. Guinard, S.M. Lee, W.H. Krueger, J.A. Miles, and J.K. Burns. 2012. Improving canopy contact olive harvester efficiency with mechanical pruning. Acta Hort. 965:83-87.

Ferguson, L., U.A. Rosa, S. CastroGarcia, S.M. Lee, J.X. Guinard, J. Burns, W.H. Krueger, N.V. O'Connell, and K. Glozer. 2010. Mechanical harvesting of California table and oil olives. Adv. Hort. Sci. 24:53-63.

Hartmann, H.T., W. Reed, J.E. Whisler, and K.W. Opitz. 1975. Mechanical harvesting of olives. Calif. Agr. 29(6):4-6.

Klonsky, K., L. Ferguson, W.H. Krueger, J.H. Connell, and P. Livingston. 2011. Sample costs to establish a high-density olive orchard and produce table olives. 6 May 2014. <http://coststudies.ucdavis. edu/current.php>.

Monselise, S.P. and E.E. Goldschmidt. 1982. Alternate bearing in fruit trees. Hort. Rev. 4:128-173.

Sarig, Y. 2012. Mechanical harvesting of fruit - Past achievements, current status and future prospects. Acta Hort. 965: $163-169$

Sarig, Y., J.F. Thompson, and G.K. Brown. 2000. Alternatives to immigrant labor? The status of fruit and vegetable harvest mechanization in the United States. 6 May 2014. <http://www.cis. org/articles/2000/back1200.html>.

Warnert, J. 2011. New methods are transforming table olive and olive oil production in California. Calif. Agr. 65(1):6-7.

Wikipedia. 2014. Shore durometer. 6 May 2014. <http://en.wikipedia.org/ wiki/Shore_durometer>.

Zipori, I., A. Dag, Y. Tugendhaft, and R. Birger. 2014. Mechanical harvesting of table olives: Harvest efficiency and fruit quality. HortScience 49:55-58. 